producers and organizers, or withdraw their patronage completely. Another important element of the crisis the animated film studios were facing was that TVP had also stopped investing in new children's TV series.

Another studio that did not survive those turbulent times was the Animated Film Studio in Cracow, although the Studio Miniatur Filmowych in Warsaw, the Cartoon Film Studio in Bielsko-Biała, and the Animated Film TV Studio in Poznań are all still operating. (The Cracow and Warsaw studios are currently [March 2015] undergoing transformations into cultur-

[13] B. Sobieszek, (Re)Animacja, http://www. e-kalejdoskop.pl/reanimacja.aspx, [accessed:

March 2, 2015]. al institutions). One can only speculate about what could have been if the state-run Semafor had survived just a few more years - until the Cinematography Act was passed in 2005 and the Polish Film Institute was established, which significantly improved the situation for both state-financed and commercial producers. However, it did not, and the epilogue to this history is manifested in the serious financial problems of the new Se-Ma-For, caused by incompetent handling of the subsidies granted by the Polish Film Institute. It seems that after all this time, Łódź film animation is still dealing with the same old issues.[13]

This work was supported by the Polish National Science Centre (DEC-2011/o1/B/HS2/o6123).

\title{
Reżyserskie szlify. Władysław Ślesicki w Szkole Filmowej (1950-1955)
}

\author{
PIOTR PŁAWUSZEWSKI
}

Uniwersytet im. Adama Mickiewicza

\section{Szkolne pisanie}

We wrześniu 1950 roku Władysław Ślesicki (urodzony 5 stycznia 1927 roku) zdał pomyślnie egzaminy wstępne do Państwowej Wyższej

[1] W tym samym roku przyjęci zostali między innymi: Andrzej Brzozowski, Sylwester Chęciński, Paweł Komorowski, Bohdan Kosiński (na wydział realizatorski); Bogusław Lambach, Zbigniew Skoczek, Jerzy Wójcik (na wydział operatorski). K. Krubski, M. Miller, Z. Turowska, W. Wiśniewski, Filmówka. Powieść o łódzkiej szkole filmowej, wyd. popr., Prószyński i S-ka, Warszawa 1998, s. $260-261$.

[2] Już wcześniej, bo w roku 1947, Władysław Ślesicki rozpoczął naukę na Uniwersytecie Warszawskim, gdzie przez rok próbował swych sił na polonistyce, by następnie przez cztery semestry studiować historię sztuki (pracując jednocześnie na stanowisku urzędniczym w Naczelnej Dyrekcji Muzeów i Ochrony Zabytków). Skąd decyzja, by podejść do egzaminów w Łodzi? Z warszawskimi klubami filmowymi i fotograficznymi oraz ama-
Szkoły Filmowej w Łodzi[1] (wydział realizatorski)[2], pisząc w tym samym czasie w kwestionariuszu rekrutacyjnym, iż film interesuje go „jako swoisty rodzaj sztuki, specjalny sposób wypowiedzi plastycznych"[3]. Przez kolejne pięć lat stykał się z materią filmową zarówno od strony stricte realizacyjnej, jak i takiej, która swój finalny kształt zyskiwała wyłącznie na papierze. Mowa tu o kilkunastu (mniej lub bardziej rozbudowanych) pracach pisemnych - szkicach scenariuszowych, analizach filmów czy konkretnych z nich postaci, opisach scen itp. Przynajmniej dwie z owych prac zasługują, by poświęcić im po latach chwilę uwagi.

$\mathrm{W}$ ramach zaliczenia jednego z przedmiotów[4] Władysław Ślesicki zobowiązany był przedstawić scenariuszowy zarys filmu fabularnego. Zaproponowaną historię opatrzył on istotnym komentarzem, podkreślającym, iż „jest ona wydarzeniem autentycznym, mającym 
miejsce w konkretnym czasie i w środowisku autentycznych ludzi” [5]. Sam fabularny pomysł można zaś streścić tak:

Warszawa, rok 1946; zburzone miasto, w okolicach tzw. Doliny Szwajcarskiej[6] zawiązuje się banda przedwcześnie samodzielnych chłopców (w wieku: 7-15); różnie wygląda ich przeszłość[7], jako grupa stanowią plejadę kolorowych charakterów (Kulas - „typ wodza, umie pociagnnąc za sobą resztę, inicjator wielu obrzędów”; Parasol - „specjalista od «dalekich wypraw», projektodawca nazwy bandy: Związek Miłości Ojczyzny”; Bobek - „malec-iskra, zawsze pierwszy w każdej przygodzie"; Poeta "pisarz bandy, mało skory do zabaw, ale za to zawsze snujący się z książką”; Romantyk - „zamyślony, chadzający często własnymi drogami”; bracia Rudy i Jajo - „żyjący zawsze w kolizji z domem"); co ich wyróżnia, to prowadzenie kroniki własnej działalności (raporty, poezje, rysunki itp.); pod koniec roku styka się z bandą osiemnastoletni Janek, działacz Związku Walki Młodych - przejęty swą pedagogiczną funkcją, stara się zdobyć zaufanie chłopców, by w efekcie oduczyć ich złych nawyków (nowy kierunek to przede wszystkim nauka, praca i odbudowa Warszawy); porozumienie pieczętuje wspólny wyjazd na letnie kolonie.

Wspomnienie owego studenckiego pomysłu wydaje się o tyle celowe, że w zmodyfikowanej formie przetrwa on i znajdzie pewne odbicie w pierwszych dwóch filmach dokumentalnych, które Władysław Ślesicki zrealizuje wespół z Kazimierzem Karabaszem zaraz po opuszczeniu łódzkiej szkoły (Gdzie diabet mówi dobranoc, 1956; Ludzie z pustego obszaru, 1957). Zmieni się wiek bohaterów (tytułowi „ludzie z pustego obszaru" będą mniej więcej przed dwudziestką), zmieni konwencja opowiadania (bo choć obie realizacje nie obejdą się bez inscenizacji, to jednak owa „autentyczność wydarzeń i postaci” pozostanie celem nadrzędnym), wreszcie - zmieni się ostateczny wydźwięk ekranowej rzeczywistości (i optymizm zastąpią raczej gorzkie diagnozy). Jednakże - zaska- torskim teatrem stykał się od kilku lat (w roku 1948 stworzył nawet teatrzyk kukiełkowy, który wystawił wiele sztuk dla dzieci, $\mathrm{w}$ tym jedną $\mathrm{z}$ autorskim tekstem swego założyciela). Jednocześnie nie do końca spełniała oczekiwania Władysława Ślesickiego studiowana przezeń historia sztuki („ze względu na brak tematyki filmowej i ograniczenie zajęć do roli odbiorcy sztuki" - jak zapisał w łódzkim kwestionariuszu rekrutacyjnym).

[3] Z materiałów archiwum PWSFTviT w Łodzi.

[4] Rękopis nie został opatrzony datą powstania, ale podpis wykładowcy ([Wadim] Berestowski) sugeruje, iż chodzi zapewne o pierwszoroczną pracę zaliczeniową z przedmiotu „Realizacja filmu".

[5] Z materiałów archiwum PWSFTviT w Łodzi. [6] Miejsce zapewne nieprzypadkowe - tam bowiem Władysław Ślesicki pod sam koniec wojny (kwiecień roku 1945) przywracał do życia przedwojenną drużynę harcerską, tzw. Ósemkę (w roku 1946 zorganizuje dla niej wyprawę do Sowiego Gniazda nad Jeziorem Drwęckim na Mazurach). Wtedy też zgłosił się do niego ze swym zastępem Konrad Szabelewski (harcerz poznany w czasie okupacji) - w roku 1948 przejmie on, właśnie po Władysławie Ślesickim, funkcję drużynowego Błękitnej Ósemki. Ta jednak, w obliczu reform, jakim podlega Związek Harcerstwa Polskiego w latach 1949-1956 (w roku 1950 funkcję kierowniczą przejmuje ZMP), ponownie przestaje istnieć. Sam Szabelewski, działając w mniejszych grupach i ze starszymi harcerzami, kontynuuje wprawdzie swą działalność, ale już nieoficjalnie po latach wspomina: „Z Władkiem czekaliśmy na moment, który wreszcie nadszedł - październik 1956! Robota «nielegalna» okazała się bardzo słuszna, bo kiedy Stefan Sosnowski (hufcowy Śródmieścia) dał mi polecenie zgłoszenia się do dyrektora liceum im. M. Reja, miałem już gotową Radę Drużyny i w rekordowym czasie (październik 1956 - czerwiec 1957) powstała Błękitna Ósemka (z kolosalnym entuzjazmem całej szkoły!), była zdolna zorganizować obóz i w lipcu pojechać do Augustowa nad Jezioro Białe, aby zbudować «murzyńską wioskę». Z Władkiem byłem zawsze $\mathrm{w}$ kontakcie: tak powstał pomysł filmu..." (z korespondencji z Konradem Szabelewskim - archiwum prywatne - P.P.). Mowa o krótkim dokumencie W gromadzie Ducha Puszczy (1957), który Władysław Ślesicki zrealizuje we współpracy z Włodzimierzem Pomianowskim. [7] W tym samym zburzonym mieście, gdzie historia ze szkolnego pomysłu bierze swój 
kująco zbieżne pozostaną sytuacje wyjściowe. Zarówno bowiem w szkolnym pomyśle, jak i dwóch wspomnianych dokumentach inicjalnym przedmiotem zainteresowania kamery jest pewna zbiorowość, żyjąca w powojennej Warszawie (dziecięca banda, mieszkańcy Targówka, starsza młodzież), która - pozostawiona sama sobie - skazana jest na żywot tyleż przygnębiający (marazm młodych, zacofanie Targówka), ile po prostu niebezpieczny (znaleziony przez chłopców $\mathrm{z}$ bandy pocisk wybucha - kilku z nich ginie). „Punkty dojścia” wyglądają już jednak całkowicie inaczej - prosty optymizm, charakterystyczny dla historycznego momentu, gdy powstawał pomysł scenariusza, po kilku latach znika - zastępuje go albo rozgoryczenie $\mathrm{z}$ niespełnionych obietnic (nieukończony dom kultury w Gdzie diabeł mówi dobranoc), albo nieukrywany znak zapytania (brak łatwej re-

początek, kończy się z kolei opowieść o dwóch braciach, bohaterach filmu Władysława Ślesickiego ...Droga daleka przed nami... (1979). Piotr (Tomasz Mędrzak) i Wojtek (Wojciech Gruca) są Zawiszakami (czyli przedstawicielami najmłodszego pokolenia w ramach Szarych Szeregów), którzy po klęsce powstania, a później po ucieczce z niemieckiego obozu pracy, starają się powrócić do zburzonej Warszawy.

[8] Co ciekawe, $\mathrm{z}$ całokształtu refleksji zawartych w pracy da się wysnuć wniosek, iż dla jej autora reportaż jest nie tyle jedną $\mathrm{z}$ odmian kina dokumentalnego, ile (głównie ze względu na „dziennikarską” dynamikę przedstawienia tematu oraz jego aktualność) rodzajem wypowiedzi zupełnie osobnym. Ów podział dobrze staje się widoczny w kontekście krótkiego omówienia filmu List górnika (1949, J. Vogel i M. Niewiarowski), który „[...] jest w jakimś stopniu i dokumentem, i reportażem. Jego forma - swobodne opowiadanie prowadzone w sposób dziennikarski, częste przerzuty akcji, powiązanie komentarzem, szerokie tło, społecznie aktualne zadania - to są cechy reportażu. Prawda zawarta w typowości losów bohatera, konflikty charakterystyczne dla środowiska, prawdziwa sceneria, autentyczni ludzie żyjący w otoczeniu bohatera, wreszcie szczera, prosta sylwetka bohatera (gra «naturszczyk») i współczesny czas akcji - to są elementy składające się na dokumentaryzm”. cepty na problemy sygnalizowane w Ludziach z pustego obszaru).

Z pewnych względów warta wspomnienia jest też inna szkolna praca Władysława Ślesickiego - powstała na czwartym roku studiów (na ocenę bardzo dobrą ocenił ją w ramach przedmiotu "historia literatury” prof. Aleksander Jackiewicz), jej temat zaś brzmiał: „Zagadnienia konstrukcji w reportażu filmowym i literackim”. Tekst, choć w przeważającej części ilustrowany filmowo-literackimi przejawami sztuki socrealistycznej (powstał w roku 1954), zawiera kilka spostrzeżeń, które uciekają od bieżącej ideologii, a świadczą o powoli nabierającej konturów reżyserskiej samoświadomości.

Omawiając kwestię często nieostrego „rozdziału między dokumentem i fabułą", Ślesicki egzemplifikuje go gatunkowymi wyznacznikami „opowieści poetyckiej (impresji)” - będącej przeważnie obrazem „miejsca” (przywołane przykłady: Warszawa - Suita warszawska, 1946, Tadeusza Makarczyńskiego; kopalnia - Kopalnia, 1947, Natalii Brzozowskiej; kamieniołomy Białe skały, 1955, Adolfa Poświatowskiego). Jak przeczytać można w pracy: „Forma opowiadania, bazowanie na autentycznym materiale (miejsca, ludzie, zdarzenia) - to są elementy zaczerpnięte z reportażu”, jednocześnie: „Sposób ujęcia tematu, skrajnie subiektywne widzenie tematu przez autora - pociągające za sobą niebezpieczeństwo deformacji, upiększenia, stylizowania rzeczywistości - to są momenty kłócące się $\mathrm{z}$ prawdziwym realistycznym reportażem" [8]. Istotna uwaga odnosi się również do pytania: jak w dokumentalnej realizacji inscenizować? „Dopuszczalna granica inscenizacji - jeżeli chcemy zachować autentyzm zdarzenia - mieści się tam, gdzie odtwarzana rzeczywistość dotyczy spraw zanotowanych w czasie dokumentacji” - pisze Ślesicki.

Oba wątki - zarówno ten dotyczący impresji poetyckiej, jak i rozumienia inscenizacji - nieustannie znajdować będą swe odzwierciedlenie już w pozaszkolnej działalności reżysera, przede wszystkim dokumentalnej. Oczywiście, ewoluować będzie ich rozumienie (zwłaszcza to dotyczące filmowej poetyckości - jej źródłem staną 
się nie tyle miejsca, ile sposoby egzystowania w nich człowieka; nie tyle „skrajnie subiektywne widzenie tematu”, ile stopniowe wypracowywanie indywidualnej poetyki owego „widzenia”).

\section{Szkolne kręcenie}

Pod koniec czerwca 1951 roku - gdy miał Władysław Ślesicki przed sobą perspektywę odbycia pierwszych praktyk wakacyjnych - jego lapidarną charakterystykę ujął jeden z egzaminacyjnych protokołów: „Dobra świadomość artystyczna i plastyczna (rozwinięta), wybitnie wrażliwy, pracowity i inteligentny" [9].

Przy filmach szkolnych praca całej ekipy twórczej to przede wszystkim poznawanie "tajemnic” warsztatowych. Tego rodzaju „odkrywcza” praca - jako praktyka wakacyjna - jest bardzo celowa, ponieważ przebiega poprzez bezpośredni eksperyment i doświadczenie każdego studenta[10]

- notował w swym „Dzienniku praktyk” Władysław Ślesicki, wtedy - czekając na rozpoczęcie czwartego roku studiów (1953/1954). Nie są to bynajmniej puste słowa, a ów niepozornie wyglądający „Dziennik” - najlepszym tego dowodem. Trudno bowiem w czasie lektury nie odnieść wrażenia, że szkolne asystowanie pozwoliło zebrać przyszłemu reżyserowi niemało inspirujących przemyśleń (ciekawie niekiedy odbijających się w jego późniejszych poczynaniach). Poniżej - kilka tego przykładów, podanych zgodnie $\mathrm{z}$ chronologicznym porządkiem kolejno odbywanych praktyk.

Pierwsza (odbyta w lipcu 1951 roku) miała charakter przede wszystkim warsztatowy. Pod okiem Wacława Kaźmierczaka uczestniczył Władysław Ślesicki w powstawaniu (już $\mathrm{w}$ montażowni) jednego $\mathrm{z}$ numerów Polskiej Kroniki Filmowej (montaż obrazu, podkładanie dźwięku, sklejanie taśmy, pisanie list montażowych), by następnie asystować Witoldowi Lesiewiczowi przy realizacji filmu 22 lipca (co między innymi umożliwiło mu wgląd w techniki inscenizacji - tu, jak notował praktykant, związanej z wręczaniem kwiatów i owacjami).

Rok 1953 stał się dla Ślesickiego źródłem zbierania cennych doświadczeń na kilku planach zdjęciowych. Od 21 maja do 23 lipca asy- stował przy tworzeniu szkolnej etiudy Władysława Marki Koreańskie dzieci[11] (zdjęcia, jak można podejrzewać, powstawały przede wszystkim w Świdrze, gdzie przebywała wtedy duża grupa koreańskich sierot wojennych, uczęszczających do miejscowej szkoły). Młodzi filmowcy, w znacznej mierze organizując filmowane zdarzenia, stawali przed problemami zarówno stricte realizacyjnymi (między innymi - „Nie wiadomo, jak filmować taniec, żeby zachować synchron przy późniejszym podłożeniu dźwięku. Czy można robić krótkie ujęcia?" - zapisywał Władysław Ślesicki w „Dzienniku”), ale też takimi, które wymagały inwencji niejako „po obu stronach kamery” (w jednej ze scen młodzi bohaterowie - filmowani w portretowych ujęciach - wspominali za pomocą rysunków wojnę: „Stworzyliśmy specjalnie uroczystą atmosferę pracy. Dzieci bardzo przejęte, grały znakomicie”, DzP). Do istotnego wniosku - zwłaszcza w kontekście przyszłych działań na terenie filmowego dokumentu - przywiodła praktykanta sytuacja, gdy dopiero na samym planie rozbudowana została (w stosunku do pierwotnych zamierzeń) scena tańca, a wszystko to za sprawą zaobserwowanych przez ekipę dziecięcych reakcji: „W filmie dokumentalnym wszelkie zmiany scenariusza, które dyktuje bieg wypadków, przyczyniają się do ożywienia i uaktualnienia filmu. [...] opinia polskich dzieci była bodźcem dla naszej decyzji” $(\mathrm{DzP})[12]$.

[9] Z materiałów archiwum PWSFTviT w Łodzi. [10] W. Ślesicki, „Dziennik praktyk” (archiwum PWSFTviT w Łodzi - kolejne cytowania $\mathrm{z}$ tego źródła oznaczone są w tekście głównym jako DzP).

[11] Niestety, w archiwum PWSFTviT wspomniana etiuda nie zachowała się. Kazimierz Karabasz, przywołując w pamięci fakt jej powstawania, podaje w wątpliwość, czy została ona w ogóle ukończona (źródło informacji: rozmowa z Kazimierzem Karabaszem, listopad 2012).

[12] „Film [Koreańskie dzieci - P.P.] dla mnie ciekawy ze względu na pracę $\mathrm{z}$ wyjątkowo trudnym «naturszczykiem» (trudność porozumienia się, niechęć dzieci do filmu). Potrzebna była znajomość chociażby podstawowych założeń pedagogi- 
Tymczasem, w lipcu 1953 roku Ślesicki objął funkcję asystenta reżysera na planie szkolnej etiudy fabularnej Kazimierza Karabasza Złote i czarne (scenariusz na podstawie fragmentu $\mathrm{Pa}$ wich piór Leona Kruczkowskiego). Okazało się to przede wszystkim okazją do prowadzenia bardzo szczegółowych notatek operatorsko-montażowych („szkice sytuacyjne, rysunki kadru, opisy kierunków i sygnałów montażowych", DzP)[13].

Miesiąc później rozpoczęła się realizacja czterech studenckich etiud fabularnych, tworzących film nowelowy Takie asy psuja wczasy (reżyser danej noweli był też każdorazowo autorem scenariusza) - Władysław Ślesicki asy-

ki i psychiki dziecka. Zjednywanie dzieci dla filmu odbywało się na drodze zawiązywania przyjaźni z nimi, wzbudzania zainteresowania różnymi atrakcjami wymyślanymi przez nas" (DzP) - w słowach tych, choć osadzonych w kontekście konkretnego filmu, pobrzmiewa echo (prawdopodobnie niezachowanej) pisemnej rozprawy dyplomowej Władysława Ślesickiego, która - wedle wspomnienia Barbary Ślesickiej, żony reżysera - dotyczyć miała pracy na planie filmowym $\mathrm{z}$ aktorem nieprofesjonalnym (można się tylko domyślać przez analogię do bronionego w tym samym czasie studium Kazimierza Karabasza „Uwagi o dźwięku w filmie dokumentalnym” - iż bazą dla zawartych w niej treści była współrealizacja ze wspomnianym Kazimierzem Karabaszem dwóch tytułów dokumentalnych: Gdzie diabeł mówi dobranoc oraz Ludzie z pustego obszaru, zaprezentowanych przez obu absolwentów jako filmy dyplomowe.

[13] Trwająca trzy lipcowe dni asystentura na planie etiudy fabularnej Andrzeja Brzozowskiego Słoneczniki ograniczyła się do obowiązków zakrojonych bardzo wąsko („[reżyser] nie korzystał z mojej współpracy w sensie twórczym, bo film był przygotowany bardzo starannie", DzP).

[14] Pozostałe trzy części cyklu to: Wczasowicz niepospolity (reż. Tadeusz Kopel), Wczasy - malkontent (reż. Andrzej Czekalski) oraz Hallo Krysiu (reż. Ryszard Pluciński). Muzycznym podkładem czołówki filmu uczyniono śpiewaną przez Martę Mirską piosenkę Wesoły pociagg (sł. K. Winkler, muz. M. Sart), powstała w tym samym roku co szkolne etiudy, w zamierzeniu zaś mającą zachęcać Polaków do korzystania z państwowych wczasów (zob. <http:// www.bibliotekapiosenki.pl/Wesoly_pociag >).

[15] Autorem zdjęć do „Kawalera” Kubiaka był Stanisław Białek. stował kolegom, jednocześnie sam podpisał się pod częścią zatytułowaną „Kawaler” Kubiak[14].

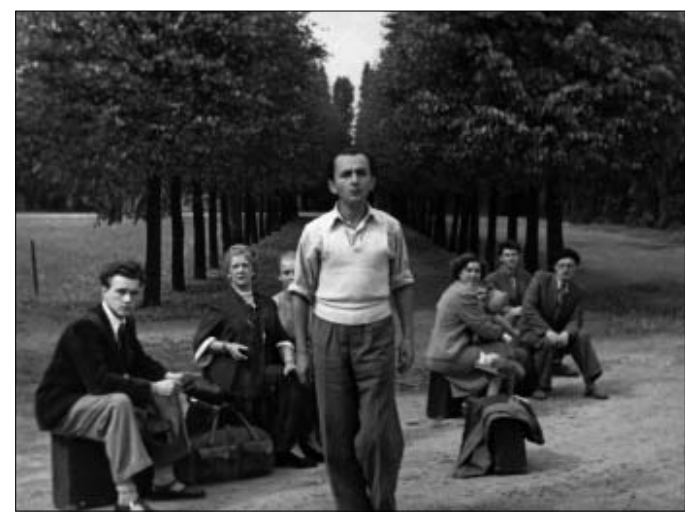

Fotos ze szkolnej etiudy Władysława Ślesickiego „Kawaler” Kubiak, w środku - odtwórca głównej roli Karol Obidniak (autor nieznany)

Trudno jednak uznać tę małą fabułę za udaną. W treści to szkicowo zarysowana historia młodego człowieka (rola Karola Obidniaka), który podszywa się pod kogoś, kim nie jest, bałamuci pociągowe towarzystwo, a ostatecznie w obawie przed zdemaskowaniem - chyłkiem opuszcza przedział. Realizacji brakuje jednak potrzebnej tu lekkości. Co szwankuje w największym stopniu? Po pierwsze, zawodzi nieudany komentarz (narrator stara się komentować ekranowe sytuacje, zazwyczaj czyni to jednak dość niezgrabnie, na przykład: „Znajomy oddalił się. Jego pytania były inżynierowi bardzo nie na rękę. Czy wróci? Chyba już nie wróci”). Po drugie, zdarzają się błędy operatorskie[15] (choćby złamanie osi w epizodzie z zapalanym papierosem; jednocześnie wypada dodać, że lepiej przemyślane zdjęcia ozdobiły część „oniryczną” etiudy, kręconą już w plenerze). Po trzecie wreszcie, zabrakło wyrazistej puenty (fałszywy inżynier Kubiak, podający się za brata poety Tadeusza Kubiaka - przestraszony sennymi wizjami - ucieka z przedziału, po czym odzywa się narrator: „To już koniec mojego opowiadania. Jeżeli pojedziecie latem na wczasy, to poszukajcie tam fałszywych inżynierów. Zobaczycie, jak misternie budują swoje drugie postacie. Można się z nich dobrze pośmiać”). 
Znacznie ciekawsza okaże się studencka próba dokumentalna Jedzie tabor, realizowana nieco później niż szkolny dokument Kazimierza Karabasza (maj-czerwiec 1954) - praca na jego planie była ostatnią szkolną praktyką Władysława Ślesickiego. Bardzo - jak pozwalają domyślać się notatki - inspirującą.

Etiuda Jak co dzień (pierwotny tytuł: Zanim zacznie się dzień pracy) opowiada o ludziach dojeżdżających codziennie $\mathrm{z}$ terenów podmiejskich do Warszawy, przy czym dojazdy te zawsze spowija widmo spóźnień, zatłoczonych składów itp. Ów „problem” udanie przyobleczono $\mathrm{w}$ filmową formę (w dużym stopniu - wbrew ówczesnym schematom[16]). Z wyczuciem skrojony został komentarz: nie dość, że w zwyczajnie rzeczowy sposób nakreśla faktycznie istniejące utrudnienia w transportowaniu ludzi do pracy, to jeszcze całkiem zgrabnie - jak to określił Mikołaj Jazdon - „stara się nawiązać kontakt $\mathrm{z}$ widzem”[17]. „Ale prawda - mówi w pewnym momencie czytający komentarz, przerywając wątek zepsutego wagonu - ciebie, pasażera pociągu elektrycznego niewiele to właściwie obchodzi. Dla ciebie tylko jedno jest ważne - przyjechać na czas do Warszawy, reszta to sprawa kolejarzy...”. Zwracają uwagę również zdjęcia (autorstwa Zbigniewa Karpowicza): plany ogólne obok zbliżeń, dynamika ujęć obok wyczuwalnych spowolnień tempa; dochodzą do tego kilkakrotnie powracające obrazy dworcowego tłumu, równie szybko zapełniającego pewną przestrzeń, co znikającego z niej - tłumu, by tak rzec, pozostawionego bez komentarza, działającego wyłącznie swą plastycznością. Nie zestarzała się ta „nastrojowa opowieść" [18] - broni się naturalnością spojrzenia na pewien niewielki wycinek świata.

Władysław Ślesicki, jak sam przyznawał, zetknął się w trakcie prac nad Jak co dzień... $\mathrm{z}$ „całym łańcuchem trudności związanych $\mathrm{z}$ realizacją tego rodzaju filmów”. Swe uogólnione refleksje ujął w formie czterech punktów:

1. Montaż - „jak należy operować planami, na co trzeba zwracać uwagę w ruchu wewnątrzkadrowym, ażeby zachować logikę i ciągłość montażową obrazu przy sekwencjach niepowiązanych akcją (np. poranek w mieście)" (DzP);
2. Inscenizacja - „,co i w jakim stopniu można inscenizować, ażeby utrzymać dokumentarną wierność opowiadania” (DzP);

3. Praca $z$ "naturszczykami” - „jaką trzeba stosować metodę, ażeby uniknąć tego, co nazywamy "grą» (w złym znaczeniu) statystów" (DzP);

4. Zdjęcia - „chwytanie życia «na gorąco», szczególnie przy scenach ulicznych, gdzie występuje tłum ludzi” (DzP).

$\mathrm{Z}$ tak sformułowanym zestawem spostrzeżeń, znaków zapytania i wyobrażeń o filmie dokumentalnym przystępował Władysław Ślesicki do pracy nad swą etiudą Jedzie tabor.

Zadanie było niełatwe już w samym założeniu tematycznym, które kierowało kamerę w stronę hermetycznej społeczności romskiej, zazwyczaj bardzo nieufnie nastawionej do "gadziów” (czyli: nie-Romów). Jednocześnie nie chodziło jedynie o czystą obserwację - staje się w pewnym momencie jasne, że krótka produkcja wpisuje się w aktualną wtedy i znacznie szerszą (niż tylko filmowa) dyskusję, dotyczącą namawiania Romów do osiadłego trybu życia[19]. Niestety,

[16] Łatwo wyobrazić sobie potencjalną realizację tej szkolnej etiudy w konwencji obowiązującego wówczas w filmowym dokumencie modelu dydaktycznego, zapewne w odmianie, którą Kazimierz Karabasz nazwał „dramatyczną”: „[...] opowieść mówiła najczęściej o grupie ludzi, którzy coś produkują lub budują, ale w pewnym momencie natrafiają na trudności. Pokonywanie tych trudności - w starannie inscenizowanych naradach produkcyjnych, sekwencjach wytężonej pracy, epizodach "groźnych» sytuacji (detale scenerii, skupione twarze, pot na czołach...) zajmowało drugą połowę filmu i prowadziło do zwycięskiego finału: ludzie przezwyciężali przeszkody i z ufnością zabierali się do dalszego działania..." (K. Karabasz, Odczytać czas, PWSFTviT, Łódź 2009, s. 38-39).

[17] M. Jazdon, Kino dokumentalne Kazimierza Karabasza, Wydawnictwo Naukowe UAM, Poznań 2009, s. 120.

[18] Ibidem, s. 15.

[19] Zob. I. Żeber-Dzikowska, E. Buchcic, A. Strumińska-Doktór, Romowie - mniejszość etniczna w Polsce - problemy, obawy, zagrożenia, 
w filmowej praktyce zaowocowało to potrzebą wpisania w obserwowany świat wymyślonej historii, dającej niejako pretekst do podejmowania wątków o charakterze społecznym. Dalsza tego konsekwencja jest z kolei taka, iż funkcjonują w ramach jednej etiudy jakby dwa światy: ten złapany „na gorąco”, ale też ten (mniej lub bardziej udanie) zainscenizowany.

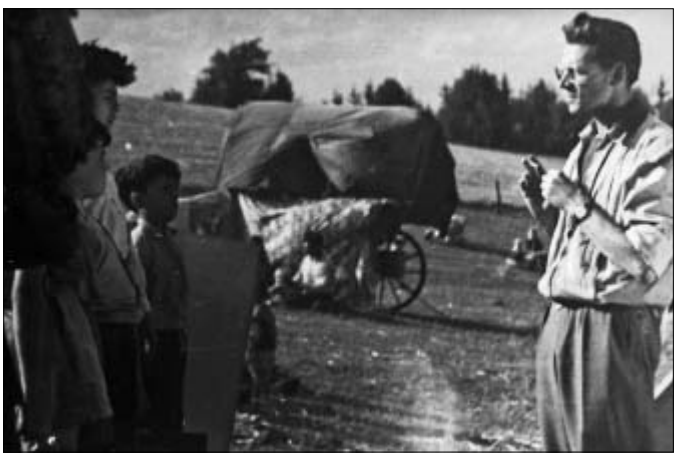

Władysław Ślesicki (po prawej) na planie etiudy Jedzie tabor (autor nieznany)

szanse wielokulturowej społeczności, „Drohiczyński Przegląd Naukowy” 2010, nr 2, s. 181-197. [20] Kamera spogląda na starą Cygankę zza ramienia kobiety, której się tu wróży: „Pani jesteś młoda, a dużo pani zmartwienie miała, i dużo pani nieprzyjemności miała. Miała pani narzeczonego, którego chciała mieć swoim mężem, ale jakaś kobita rozbiła pani szczęście.

A teraz pani masz narzeczonego, którego chcesz..." (głos zostaje wyciszony, kamera spokojnym ruchem przesuwa się $\mathrm{w}$ stronę talii rozłożonych kart).

[21] Oto tekst komentarza, podłożony pod ujęcia z Romami osiadłymi w mieście: „«Mageredo skalani» [w opracowaniach, do których udało się dotrzeć $\mathrm{w}$ trakcie prac nad tekstem, termin ten funkcjonuje w postaci: «magerdo» - P.P.], tak nazywają Cyganie swoich rodaków, którzy zdradzili odwieczne zwyczaje, porzucili wędrówkę. Dawni Kalderari - kotlarze, Kovaccio - kowale, osiedlili się w domach, pracują w fabrykach, ich dzieci chodzą do szkół. Ale nawet mageredo nie potrafią wyzbyć się dawnych przyzwyczajeń. Gdy tylko zaświeci słońce, pustoszeją mieszkania, całe rodziny przenoszą się na trawniki. Odżywają dawne wspomnienia. Tu, pod gołym niebem, jest prawie tak samo, jak na leśnym biwaku, w taborze".
Do największych osiągnięć w ramach tego pierwszego należy bez wątpienia ujęcie $z$ wróżącą z kart Cyganką (zarejestrowane ze stuprocentowym dźwiękiem) - trwa tylko dwadzieścia sekund (cała etiuda - niecałe 13 minut), ale to być może owa śpiewnie wyrecytowana przeszłość zapada w pamięć najbardziej[20]. Zwracają tė̇ na siebie uwagę sceny uliczne ( $\mathrm{z}$ tłumem obserwującym popisy młodej tancerki), gdy obok spojrzeń ukradkiem kierowanych w stronę kamery dostrzega się i takie, które autentycznie pochłania cygański spektakl. To samo dotyczy obrazów koczującego za miastem taboru - naturalność niektórych ujęć (zwłaszcza tych z małymi dziećmi - płaczącymi, niezdarnie myjącymi się itp.) nie pozwala wątpić, że powstały one dzięki umiejętnemu podpatrywaniu.

Niemniej jednak Jedzie tabor to także historia: Jasza chce poślubić Marinkę (to ona tańczyła przed miejską publicznością), na co, wedle obyczaju, zgodę wyrazić musi jej ojciec, Giulino. Chłopak wędruje więc po obcych mu, szerokich ulicach, spogląda w kierunku sklepowych wystaw, by w końcu - z prezentami pod pachą - zjawić się w taborze. Przyszłemu teściowi wręcza butelkę wódki, wybrance zaś - pantofle (znak propozycji ślubnej). Otoczenie wiwatuje, szczęśliwa para rusza na spacer i dociera na skraj otwartej przestrzeni, stamtąd zaś widać już wysokie budowle miasta. Nieprzypadkowo. Streszczoną powyżej opowiastkę trzeba bowiem zobaczyć w odpowiednim kontekście, który w ramach etiudy Ślesickiego - kreuje przede wszystkim komentarz. Komentarz, dodajmy, dobrze oddający wspomnianą dwoistość ekranowej rzeczywistości. Są momenty, gdy próbuje on, nieco w poetyce tekstu etnograficznego, opisać i wytłumaczyć oglądany właśnie fragment świata[21]. Nieco częściej podąża on jednak tropem szkicowej fabuły, czyniąc ją, jako się rzekło, pretekstem do przemycania myśli o charakterze bardziej ogólnym, a związanych z trybem życia wędrującego taboru. Trzeba przyznać, że tekst komentarza - choć wielokrotnie obciążający obraz zbyt słabo maskowaną dydaktycznością ma swą świadomie ukształtowaną, wewnętrzną linię rozwojową. Z początku, gdy Jasza wędruje 
przez miasto, w słowach narratora pobrzmiewa porozumienie $\mathrm{z}$ jego tokiem myślenia:

Niedobrze czuje się Cygan w mieście. Miasto ma swoje uroki, prawda, ale Cygana razi zgiełk uliczny, niepokoi pośpiech. Jasza nie rozumie, jak można pracować w ciemnych fabrykach, w biurach, jak można mieszkać w wysokich murowanych domach, $\mathrm{w}$ ciasnych mieszkaniach, gdzie widać tylko wąski skrawek nieba i gdzie nie czuje się zapachu pól. Nie, stanowczo miejsce Cygana jest w taborze, na wozie.

Już za moment jednak - jako komentarz do pojawienia się grupki romskich dzieci z pił$\mathrm{ka}$ - zadane zostaną pytania ( $\mathrm{z}$ użyciem mowy pozornie zależnej): „Dzieci cygańskie? Czy to możliwe? A więc tu, w mieście, żyją Cyganie?”. To pierwszy sygnał nieobecnego dotąd wątku przekonania, że osiadły tryb życia nie tylko jest dla taboru możliwy, ale i pożądany. Głos ten staje się jeszcze bardziej słyszalny (aż do sformułowania przekazu wprost) w kontekście późniejszych scen z obozowiskiem:

Tak niewiele trzeba, aby ręce same chwyciły za skrzypki, a nogi złożyły się do tańca. Piękne jest życie w obozie. Ale to piękne życie trwa krótko. Po ciepłych wieczorach przychodzą chłodne noce. Nie uchroni przed zimnem ani poniewierką ani pierzyna, ani dziurawa płachta cygańskiego szatry. Źle pojęte przywiązanie do swobody, lenistwo, odstręczają Cyganów od pracy. Jednak coraz częstsze są chwile, kiedy każdy Cygan rozumie, że życie na wozie przestało mieć sens i cel. Stało się nie tylko trudne, ale i upokarzające.

Za próbę zniwelowania dystansu między komentarzem a portretowanym światem uznać trzeba krótkie, wyraźnie inscenizowane scenki dialogowe, gdy głos zza kadru zdaje się (w dosłownym tego słowa znaczeniu) tłumaczyć na polski zdania formułowane w cygańskim języku romani. Niestety, to najsłabsze fragmenty etiudy. Z dwóch powodów: (1) nieprzekonująco, zbyt dosłownie brzmią same wypowiedzi (Jasza do ojca Marinki: „Wujku Giulino, w mieście są Cyganie, mówią naszym językiem, śpiewają nasze pieśni. Mieszkają w domach, a ich dzieci chodzą do szkoły. Nie są wcale źli, dlaczego oni są mageredo?"); (2) nie udało się Ślesickiemu uniknąć owej „gry” naturszczyków, o której wspominał w swych praktykanckich notatkach - stąd choćby „wujek Giulino” grzeszy przesadną ekspresją, a po twarzy jednej z zapalczywie kłócących się o pieniądze kobiet przemyka delikatny uśmiech[22]. Ostatecznie, tabor ponownie rusza $\mathrm{w}$ drogę, a nad melancholijnym obrazem wolno toczących się wozów i rzewnym śpiewem Cyganki unosi się głos komentarza, tu już bezpośrednio skierowanego do widza: „Gdybyście jednak kiedyś, idąc ulicą swego miasta, dostrzegli w tłumie robotników Jaszę, cygańskiego chłopaka, nie zdziwcie się. Będzie to znaczyło, że Jasza nie zląkł się klątwy mageredo, a znalazł dla siebie inną cygańską nazwę: godorom - Cygan mądry”.

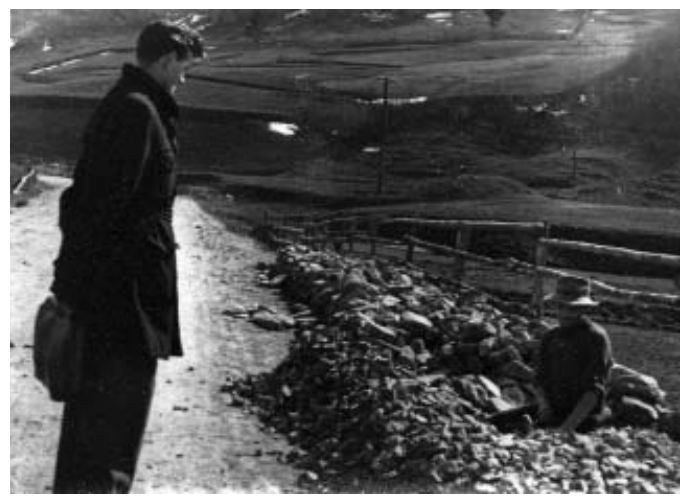

Władysław Ślesicki (po lewej) w przerwie między zdjęciami do etiudy Jedzie tabor (autor nieznany)

W szkole oceniono, iż temat filmu był „wyjątkowo trudny”, a „rezultaty słabe”[23] - to jednak nie do końca sprawiedliwa opinia. Etiuda Jedzie tabor byłaby istotnie „słaba”, gdyby pozbawić ją tych wszystkich elementów, które jej autor twórczo rozwinie w swych kolejnych filmach. Pierwsze próby dyskretnej obserwa-

[22] Na marginesie warto nadmienić, że nierzadko z problemem niepotrafiącego opanować wesołości bohatera (choćby w scenie $\mathrm{z}$ łapaniem i zabijaniem łososia) nie poradził sobie również w trakcie realizacji Nanuka $z$ Pólnocy (1922) Robert Flaherty (zob. Shari M. Huhndorf, Nanook and His Contemporaries: Imaging Eskimos in American Culture, 1897-1922, „Critical Inquiry”, vol. 27, Autumn 200o, no. 1, s. 122-148).

[23] Z materiałów archiwum PWSFTviT w Łodzi. 
cji, staranna kompozycja (film rozpoczyna ujęcie $\mathrm{z}$ taborem wolno sunącym $\mathrm{w}$ stronę kamery, zamyka - obraz analogiczny, tyle że kamera obserwuje tabor oddalający się od niej), nieśmiałe ślady talentu do opowiadania przede wszystkim obrazem (ujęcie w planie totalnym - w oddali budowle miasta, bliżej: otwarta przestrzeń, po której wolno przechadza się koń - dobrze oddaje to sposób myślenia bohaterów, dla których między tymi dwoma planami krajobrazu przebiega trudna do zlekceważenia granica) - to bez wątpienia atuty studenckiej produkcji Ślesickiego. Atuty - by raz jeszcze do tego wrócić - sąsiadujące $\mathrm{z}$ dydaktyzującym komentarzem, niepotrzebnie

[24] Bardzo możliwe, że był nim Jerzy Bossak, ówczesny profesor - a od roku 1956 dzie-

kan - Wydziału Reżyserii PWSFTviT. Także po zakończeniu studiów Władysław Ślesicki często kontaktował się ze swym wykładowcą, konsultując pomysły, pytając o radę itp. Po wielu latach, poproszony o tekst do książki wydanej z okazji 50. rocznicy powstania warszawskiej Wytwórni Filmów Dokumentalnych i Fabularnych, napisał między innymi: „Uważam siebie za dość chłonnego obserwatora - ciśnienie osobistych fascynacji rodziło konieczność «spowiedzi», podzielenia się spostrzeżeniami. Taką możliwość znalazłem w szkole filmowej, w grupie profesora Jerzego Bossaka, ojca polskiego dokumentu. Nie sposób przecenić jego zasług w twórczym rozwoju każdego z nas. [...] Dzięki mądrości i tolerancji profesora Jerzego Bossaka polski dokument w swoim złotym okresie mógł się rozwijać w szerokim wachlarzu form. I ja tam znalazłem miejsce dla siebie". Chetmska 21. 50 lat Wytwórni Filmów Dokumentalnych i Fabularnych $w$ Warszawie, red. B. Janicka, A. Kołodyński, WFDiF, Warszawa 2000, s. 105. organizującą rzeczywistość fabułą oraz mało udanymi inscenizacjami.

Po niecałych dziesięciu latach reżyser wróci z kamerą do taboru - by nakręcić jeden ze swych najważniejszych dokumentów - Zanim opadna liście (1964). Różnica w efekcie artystycznym będzie, rzecz oczywista, łatwo zauważalna. Nie zmienia to faktu, że pierwszy samodzielnie wyreżyserowany przez Władysława Ślesickiego film dokumentalny już nieśmiało tę przyszłość zapowiadał.

14 czerwca 1955 roku (czyli na zakończenie ostatniego semestru studiów) wydana została (niestety, bez podpisu autora[24]) przytoczona poniżej „Opinia dziekanatu”:

Inteligencja - na czwórkę. [...] jest to chłopak o sporej wrażliwości artystycznej, sporo rozumie, ale - jak wszyscy - bardzo mało umie. Jest to w ogóle sprawa generalna: co zrobić z tymi chłopcami, którzy mają już szkołę za sobą, ale tak mało wiedzą o swoim przyszłym zawodzie... Myślę, że nie miałoby sensu trzymać ich nadal w szkole, nie można również dyskwalifikować ich, bo powody braku wiadomości są różne... Trzeba im chyba pozwolić terminować [...], a po tym okaże się, kto $\mathrm{z}$ nich może pretendować do samodzielności. Ślesicki ma chyba odchylenie raczej „fabularne” niż dokumentalne.

Ciekawi szczególnie konkludująca diagnoza. Bo choć raczej nietrafnie ocenia ujawnione $\mathrm{w}$ niedługim czasie predyspozycje reżysera, to przecież jednak pobrzmiewa w niej dalekie echo decyzji o porzuceniu filmowego dokumentu. Dokumentu, który w drugiej połowie lat 50. miał w Polsce rozszerzyć swe artystyczno-poznawcze możliwości. Niemała w tym procesie zasługa reżyserskiego duetu: Karabasz Ślesicki, to już jednak historia, która toczy się poza murami łódzkiej Szkoły Filmowej. 